\title{
What Drives Support for Social Distancing? Pandemic Politics, Securitisation and Crisis Management in Britain
}

Georgios Karyotis1,* , John Connolly2, Sofía Collignon3, Andrew Judge1, Iakovos Makropoulos4, Wolfgang Rüdig4 and Dimitris Skleparis5

1University of Glasgow, Glasgow, UK, 2University of the West of Scotland, Glasgow, UK, 3Royal Holloway, University of London, UK, 4University of Strathclyde, Glasgow, Scotland and 5Newcastle University, Newcastle upon Tyne, UK

*E-mail: Georgios.Karyotis@glasgow.ac.uk

\begin{abstract}
Support for social distancing measures across the globe was high at the start of the COVID-19 pandemic but increasingly came under pressure. Focusing on the UK, this article aims to explore what drove public support for social distancing measures during the first lockdown, through mixed methods. In line with insights from crisis management studies and security studies, thematic analysis is employed to map the main frames promoted by the government and other actors on the nature/severity, blame/responsibility and appropriate responses to the pandemic. The impact of these framing contests on public attitudes is explored through a series of regression analyses, drawing on a representative survey of the UK population $(n=2,100)$ and controlling for other influences. The overall analysis challenges the dominant understanding that support for measures is driven by socio-economic influences. Instead, it is argued, the key to harnessing public support for measures lies in the ability of the government to prevail in framing contests, both diagnostic and prognostic, and produce a coherent crisis narrative.
\end{abstract}

\section{Keywords}

COVID-19; crisis management; public attitudes; framing; political behaviour; securitisation; mixed methods 


\section{Introduction}

Following the World Health Organisation's (WHO) declaration of a global health emergency on January $30^{\text {th }} 2020$, upgraded to a 'pandemic' on $11^{\text {th }}$ March (WHO, 2020), governments across the world implemented a series of public health measures to delay the spread of the virus. These measures focused on social distancing, long considered to be the cornerstone of public health interventions to widespread disease transmission in general (Kass, 2001) and for containing COVID-19 in particular (Matrajt and Leung, 2020). Most governments experienced a high degree of trust and acceptance of the measures to contain the spread of the virus (Bol et al., 2020). However, continued acceptance of lockdown measures has increasingly come under pressure in many countries. Epidemiologists would attribute this to the 'prevention paradox', whereby measures that have a major impact on public health are difficult to implement, if individuals perceive a low probability of being affected by the disease (Rose, 1985). This paradox has an urgent practical and political dimension, since measures that limit civil liberties, democratic rights and economic activities may face strong public opposition over time, potentially fuelled by conspiracy theories and populist mobilisations and further undermined by subsequent policy failures and contradictions. The aim of this article is to provide a rigorous and holistic analysis of the drivers of public support for social distancing, a question of urgent comparative importance, drawing on empirical data collected at the start of the crisis, which provide a relatively clean 'laboratory setting' to study political behaviour and attitudes, at their formative stage.

Although current research indicates that support for social distancing is influenced by multiple factors, studies have yet to consider the interplay between these influences to determine their relative explanatory power. Early empirical studies focussed on healthrelated variables and demographic characteristics to account for behavioural differences between social groups, noting decreased compliance among people with low educational attainment and health literacy (Wolf et al., 2020), among members of racial/ethnic minorities (e.g. Van Scoy et al., 2020), and among men and those experiencing health or economic vulnerability (Lancet, 2020). The role of context to account for individual attitudes and behaviours is also highlighted implicitly by Lennon et al (2020: 160), who found 'marked regional differences in intent to follow key public health recommendations'. Socio-political factors have been shown to be important for explaining regional variation, with higher levels of compliance, for example, reported in the USA among residents in Democratic counties, compared to Republican ones (Painter and Qiu 2020). More broadly, trust in institutions, ideology and partisanship have consistently been found to influence public attitudes during the pandemic (Barrios and Hochberg, 2020; Allcott et al., 2020).

One specific area that has, so far, received surprisingly little attention concerns the effect of political cues on public attitudes, which in previous crises was shown to drive support for exceptional and unprecedented measures, controlling for socio-economic and political factors (e.g. Karyotis and Rüdig, 2015). After all, persuasion, short of pure coercion, 'is the most direct way to mobilise or paralyse a group' (Cruz, 2000: 275) and is appropriately considered 'the main currency of crisis management' ('t Hart and Tindall, 2009, p. 23). The ability of political elites to use language to set the parameters for audiences to 
interpret, categorise and evaluate complex or unexpected developments, such as the pandemic, is indeed amplified at times of crises (Benford and Snow, 2000). Any crisis tends to generate fast and contradictory information, which form competing frames concerning its nature and severity, the responsibility for its occurrence or escalation, and the appropriate response and sacrifices it requires to curtail its development, so framing, around these exact dimensions, takes central stage (Entman, 1993; Boin, et al., 2009). Simonov et al (2020) demonstrated that exposure to Fox News coverage predicts opposition to social distancing, which is suggestive of an effect of differential messaging by politicians, yet more systematic efforts are required to connect the attitudes of citizens with the messages of their leaders during a crisis.

The article seeks to address this gap, by synthesising insights from crisis management, political behaviour and securitisation literatures, and utilising Britain, as an 'extreme casestudy'. Extreme case-studies correspond to a case that is considered to be prototypical or paradigmatic of a broader process or development. The focus on a case that lies far away from the mean of a given distribution facilitates exploratory analysis that may disconfirm or confirm a prevalent understanding (see Seawright and Gerring, 2008). The lacklustre response of the United Kingdom (UK) government at the start of the pandemic, when nearly all countries in the world had taken decisive measures to contain the spread of the virus, provides an ideal setting. This allows us to empirically test the prevalent understanding in the emerging literature on COVID-19, and public debates, that support for social distancing is largely dependent on personal circumstances, health and economic vulnerabilities, demographic characteristics and political factors, such as ideology and trust. Through a series of regression analyses, we explore the explanatory power of corresponding models, while also contrasting them to models that are explicitly drawn from the crisis management literature and, specifically, the key framing contests in the UK about the nature, severity, responsibility and appropriate response to the pandemic.

To analyse the drivers of support for social distancing, the article employs mixed methods. First, thematic analysis of public discourse is employed to map how the main frames that crisis management theory draws attention to were represented in public debates during the first month of the UK lockdown, and by whom. Second, to assess the extent to which these key frames had an impact on public attitudes, we analyse original and pertinent survey evidence of a representative sample of the UK population $(n=2,100)$, administered online between 10 and 15 April 2020, soon after the initial implementation of social distancing measures but prior to the subsequent politicisation around the government's crisis management performance. We begin the analysis by engaging with theoretical debates about the role of framing in crisis management and security studies, and their implications for pandemic politics, before introducing our data and methods. Next, framing contests in the UK on the nature, severity, blame attribution and the role of science are matched with public attitudes along the same dimensions, showing a remarkable degree of alignment, in most cases. Our analysis of unique and pertinent survey data in the final section demonstrates that the variables inspired by the crisis management and securitisation literatures, produce, by far, the strongest model to explain support, or opposition, for social distancing in the UK, in comparison to models that rely on health, economic, and political variables. This challenges the prevailing understanding on what 
drives public attitudes and has significant theoretical and empirical implications, which are explored in the conclusion.

\section{Crisis Management, Securitisation Theory and Pandemic Politics}

The role of elite framing and language as drivers of public attitudes is emphasised by both crisis management theory and securitisation research, among others. From a crisis management perspective, crises can be understood as the combined products of sudden events and social perceptions, largely defined by the dominant narratives surrounding them (Rosenthal, et al., 1989). In highly polarised contexts, this produces greater competition between political actors, attempting to either 'contain or exploit crisis-induced opportunity space for political posturing and policy change' (t' Hart and Tindall, 2009, p. 23). From a social constructivist understanding of security (Buzan et al., 1998), elites usually political leaders -, employ the rhetoric of 'existential threat' in order to mobilise support for the implementation of 'extraordinary' measures, with the consent of a specific audience - usually the general public (Williams 1998: 435). Henceforth, convincing an empowering audience that a 'referent object' they value is facing an existential threat provides authorities with a green light to legitimise exceptional emergency measures, beyond 'normal politics', a process known as 'securitisation' (Buzan et al, 1998).

From both perspectives, political elites, especially those holding office, are assumed to be the protagonists of crisis management and, by virtue of their position and/or expertise, the dominant actors in producing 'legitimate' security discourses. In the face of a crisis, governments have no choice but to 'attempt to reduce public and political uncertainty and inspire confidence in crisis leaders by formulating and imposing a convincing narrative' (Boin et al., 2017, p.79). Elites manipulate, strategise and fight to have their frame accepted as the dominant narrative (Brandström and Kuipers, 2003; Stone, 2012). Therefore, frames are typically in direct competition with one another, while also constrained by 'pre-existing meaning structures or schemas' that apply to a particular context (Scheufele 1999, p.105). Successful framing 'occurs when in the course of describing a campaign, issue, problem, or event, a speaker's emphasis on a subset of potentially relevant considerations causes individuals to focus on those considerations when constructing their opinions' (Druckman 2001, p. 1042). Making some aspects of a crisis more salient in discourse promotes a particular causal interpretation, moral evaluation, and treatment/recommendation (Entman 1993, p. 52). The implication is that when it comes to the politics of crisis and security, perceptions matter more than the objective reality, with political elites typically assumed to be the main actors that shape, from the top-down, public attitudes and behaviours.

However, in the context of the COVID-19 pandemic, there are two main reasons why this may not necessarily apply. First, prior research has shown that with regards to health issues, domestic and international health experts play an equally, if not more important role than domestic political elites in facilitating support for extraordinary public health interventions (Bengtsson and Rhinard 2019; Curley and Herington 2011; Davies 2008). Second, in the face of a global threat, publics may come to appreciate its severity through 
a multitude of sources, and, accordingly, pressure their governments to act. Indeed, infectious disease outbreaks are characteristic of a global challenge that impacts upon populations, irrespective of the political borders that surround them, with the timing of response being of the essence (Curley and Herington 2011). In protracted crises, similarly to protracted conflicts (see Adamides 2020), securitisation processes are not expected to be limited to the mainstream top-down path, but may also follow a horizontal and even bottom-up trajectory, particularly as the salience of the threat raises and countermeasures are adopted internationally. Overall, and drawing on the extant literature, it is possible to inductively identify four main battlegrounds in crisis-induced framing contests, two of them 'diagnostic', concerned with how a problem is represented, and two 'prognostic', concerned with the articulation of concrete solutions to the problem (Benford and Snow, 2000).

The first contest is about the severity and nature of the crisis. Global health issues are by no means new, however their salience only increased after the end of the Cold War, which had orientated security agendas solely around external military threats from other states (Walt, 1991). Since the 1990s, states, particularly in the West, and international organisations like the WHO, increased their efforts to define infectious diseases as an urgent security threat that necessitates the design of new rules and behaviours for its successful containment (Davies 2008). Health experts, economists, defence strategists, academics, entrepreneurs and politicians sounded the alarm about the dire potential consequences on health, economic, defence and national security infrastructures, if governments failed to prepare adequately for the outbreak and spread of a fatal contagious disease. For example, the WHO (2005) often referred to the inescapability of a deadly pandemic influenza that could kill anywhere between 2 and 12 million people globally. Other actors and agents used war-like metaphors to stress the severity and multifaceted nature of natural or manufactured deadly pathogens (Sanders and Chopra, 2003). Econometric models and forecasts, such as the one issued by the Australian Treasury amid the 'avian flu' epidemic, which predicted that an outbreak of pandemic influenza could cause a 'recession about half the size of the Great Depression' (Hartcher and Garnaut, 2006), were also used to highlight the potential magnitude of such a threat. However, typically, domestic contextual factors and electoral calculations determine whether and when political elites will downplay or emphasise how serious a threat is, and how it should be principally understood (Boin, et al., 2009).

Indeed, during the COVID-19 pandemic, some governments, notably the British, delayed framing the virus as an existential threat and introducing emergency measures, which may have contributed to the UK having the highest death count in Europe. According to securitisation theory, however, the objective severity of a threat, measured, for example in terms of casualties, is not important; what matters is perceived severity (Buzan et al, 1998). Of course, as Kamradt-Scott and Mclnnes (2012: S99) note, 'equally important is the need for the frames to be based on an accepted empirically valid reality', but in a multifaceted crisis, there are opportunities for elite actors to draw attention to a sub-set of considerations and set the parameters within which the severity and nature of a threat is interpreted by the public. Evidence from Italy by Briscese et al (2020) indicates that the management of public expectations, through effective communication mechanisms, is a 
predictor of support for social distancing measures, more so than objective markers, such as the duration of lockdowns. Similarly, in the UK case, we would expect that the actual number of deaths does not influence public attitudes. Furthermore, the all-encompassing nature of a pandemic provides options for elite actors to draw differential attention not only to its immediate public health implications, but also to its economic, social and political repercussions. The 'referent object' that needs to be protected is not fixed or predetermined, according to securitisation theory, but socially constructed and projected in discourses, which invoke the urgency for decisive action to ensure the survival of individual lives, socio-political values/identities and/or important state institutions and interests (Buzan et al, 1998). During the pandemic, human lives are the obvious referent object in a global health crisis, but the crisis could also be represented as a threat to other things that are valued in a specific national context, such as economic and political values, social identities, or important structures and institutions. Framing dynamics around the nature and severity of the pandemic crisis, we would expect, influence public understandings and behaviours in ways that have not been previously studied empirically.

The second contest involves blame attribution dynamics - efforts to avoid culpability and manoeuvrings to allocate responsibility (Hood, 2002; Kuipers and Brändström, 2020). This contest may not only make or break the viability of implemented policies, but also the political fortunes of incumbent leaders (t'Hart \& Tindall, 2009, p. 28). While government elites have an electoral self-interest in avoiding being held accountable for negative developments, we would expect that this would also likely undermine public support for measures to deal with the crisis. To prevent this, it is common for governments to adopt an exogenous frame, whereby the reasons for the emergence of a crisis, or its escalation, are portrayed as beyond their control, in order to deflect blame and attention away from any policy mishaps ('t Hart and Tindall, 2009, p. 28-29). This can be done through defensive narratives, like disqualifying critics, accusing the accusers, or diverting the blame to others (Bovens, 1999). However, it may also be achieved through positive messages about the need for individuals to take action for the 'greater good'. We would expect those with perceived declining probabilities of contracting COVID-19 to be less likely to support social distancing measures, as this is a feature of not only the 'prevention paradox' (Rose 1985) but also the 'collective action problem' (Olson, 1965). Yet, even individuals who might not be concerned about their personal health vulnerability would be likely to support measures, if they were instilled, through successful framing, with positive incentives to contribute to a 'public good'.

The third contest is about remedies and trade-offs - competing frames about how to respond to a crisis, and at what cost. Securitisation research shows that once an issue has been established as an existential threat, then extraordinary measures can be legitimised, even at the cost of sacrificing other values (Buzan et al., 1998). Lessons from the Great Recession provide a preliminary blueprint on the key frames that typically compete during a crisis (t'Hart and Tindall, 2009; Boin, 2009; Karyotis and Rüdig, 2015). From these, the most potent framing strategy to mobilise public support for social distancing measures as the appropriate remedy at the start of the crisis is likely to be the notion that 'There Is No Alternative' (TINA), at least until a vaccine becomes available. Framing the crisis as an opportunity may help energise public understandings to embrace 
the measures, in the expectation that this would serve higher-order objectives and values, ultimately emerging stronger from the crisis. The opposite effect is achieved by fatalistic frames, such as that 'nothing can be done' to stop the spread of COVID-19, thus deincentivising public support and compliance with measures. Frames about the fairness of the measures may also target the government, which could indirectly impact on public support. While this list of key prognostic frames is by no means exhaustive, they have been most salient in previous crises, and on this basis, we can expect that people who embrace the TINA and 'crisis as opportunity' frames would support social distancing, while those embracing the fatalist and fairness frames would oppose it.

Cutting across these framing contests is a fourth contest about the role of science and scientific experts. This is a rather novel and emerging dimension in crisis management but not a surprising one, given that previous research on health security found health experts to often be more influential than politicians in shaping understandings, as discussed above. In a fast-moving and confusing context, it is essential that governments draw on the latest scientific evidence to inform debates about the severity and nature of a threat, but also, crucially, to determine appropriate diagnostics and treatments (Berling, 2011). During the pandemic, this was celebrated as 'a welcome return of scientific expertise to the heart of government', since governments need scientific evidence 'right here, right now', to guide their responses, in real time (Bronk 2021). Indeed, governments across the world have repeatedly and emphatically claimed to be 'following the science', to legitimise the measures designed to reduce the spread of COVID-19. This, too, is crucial, since Swami and Barron (2000) found that analytical thinking and rejection of COVID-19 conspiracy theories are strongly associated with compliance with social distancing. In our case, we would similarly expect that those that reject conspiracy theories about the origins of COVID-19 to be more likely to support social distancing.

Science is invoked during the pandemic as an integral part of governmental crisis communications and promoted frames, in ways that could potentially impact on public attitudes. Nevertheless, the literature calls for some caution to be exercised about this type of framing. For one, research on advice-taking suggests that 'decision-makers tend to overweight their opinions relative to those of an advisor leading to inferior outcomes, even when the advisor is recognized as a highly-trained expert' (Simanov et al., 2020: 2). Furthermore, rather than 'de facto' and absolute truths, scientific results should be treated as provisional and open to audit by other scientists, as well as appropriate revisions, when new evidence becomes available (Bronk, 2021). These open up the possibility for the politicisation of science, in ways that allow governments to push agendas and justify political and policy choices, while shielding themselves from responsibility for outcomes. For example, evidence from the UK and the USA indicate that decision-makers may suppress scientific perspectives that are not congruent with their promoted crisis narrative or contradict other political objectives and values (Abbasi, 2020). After all, as Bronk (2021) reminds us, 'science can neither substitute for political choices between competing goals nor replace the need for nuanced judgment of the multifaceted nature of specific problems [...] science cannot determine what is the right value choice to make'. Anti-science attitudes, have recently been linked with a revolt against the 'overeducated' (Szabados 2019), perhaps reflecting deeper divides in society, but the question that is more directly 
susceptible to framing effects during a crisis is whether people trust the scientific experts that advise their government. Our expectation is that those who do, would be more likely to support social distancing, irrespective of their general attitudes towards science. Overall, our empirical analysis allows us to explore how these four framing contests played out in debates in the UK at the start of the crisis, and the extent to which the public's positioning along these key dimensions drives support, or opposition, for social distancing, which is our principal aim.

\section{Data and Methods}

Crisis management research in political and policy studies has generally focused on the role of political leaders and institutional responses to threats and crises, at multiple levels of governance (e.g. Christensen et al., 2016; Drennan et al 2016; Boin et al., 2003; 2010; 2016). An explanation of this is that crisis research in politics emerges from the public administration (public management) and organisational (management) disciplines. Indeed, the word 'management' itself brings with it connotations of resource mobilisation based on command and control orientation to governance. ${ }^{1}$ With this in mind, crisis studies have had a degree of qualitative bias because the implications of the decisions of managers and leaders (and their deficiencies) has meant that studies, and their accompanying methods, adopt more of a relational perspective. For example, qualitative case study designs, using interviews and focus groups, are commonly employed to study the nature of collaborations between actors within different phases of the crisis management process. The outcome of this is that the 'structures' or institutions of crisis governance often outweigh the attention given to the roles and perspectives of the 'agents' (or the public) within crisis research.

As a result, there is a distinct lack of crisis management studies which employ quantitative methods to empirically measure the extent to which frames correspond to, or indeed, influence public understandings and attitudes during a crisis. The same methodological imbalance is present in securitisation theory. Buzan et al (1998: 176-7) prescribe discourse analysis as the 'obvious method' to study security, without the need for 'sophisticated linguistic or quantitative techniques'. Instead, they argue, 'the technique is simple: Read, looking for arguments that take the rhetorical and logical form defined here as Security'. Accordingly, 'most securitisation research focusses on elite constructions of the security frame alone, without consideration of the public's evaluations of this message' (Paterson and Karyotis, 2020: 17). This article helps to address the poorly cultivated quantitative field of crisis management and securitisation research, proposing the use of mixed methods, as a potent way to expand the scope and contribution of these fields.

First, we use thematic analysis to map, in the UK context, the four key framing contests identified in the literature review. Thematic analysis is a method for searching, identifying

\footnotetext{
1 Another reason why the crisis management literature has generally privileged qualitative methodologies is that the field is dispersed across three largely fragmented bodies of literature: framing theory, security studies, and crisis studies (Eriksson, 2020).
} 
and analysing theoretically-informed patterns of meaning, or else themes, in a dataset (Daly, Kellehear and Gliksman, 1997). Our dataset comprised of news articles and official elite communication, that is state, government and opposition officials', as well as scientific experts' and advisers' public announcements and press releases, which were published between 15 February 2020 (i.e. two weeks before the first recorded cases of local transmission in the UK) and 15 April 2020 (i.e. the end date of our survey). This constitutes the timeframe for our study. Data was collected and analysed manually by two independent coders. We followed a hybrid approach to thematic analysis, drawing upon both the data-driven (i.e. inductive) (see Boyatzis, 1998) and theoretically-informed (i.e. deductive) approaches (see Crabtree and Miller, 1999). This was an iterative and reflexive process with the data collection and analysis being conducted concurrently. Data collection and analysis was based on four both deductively and inductively generated broad thematic categories: severity (i.e. death projections/estimates) and nature (i.e. health, economic, social, political repercussions of the pandemic); Blame/Responsibility (i.e. actors and phenomena associated with the spread of the virus); political value choices (i.e. fatalism; TINA; 'fairness'; 'opportunity') and policy trade-offs (i.e. public health vis a vis civil liberties and the economy); and references to the role of science and scientific expertise in pandemic policy-making. Regular coding clinics were held among the two researchers to ensure the reliability of the data collection and analysis process.

Second, we conduct a series of OLS regression analyses to determine what drives support for social distancing in the UK. Since we are interested in attitudes, rather than behaviours, as dependent variable we focus on support for 'allowing people to leave their homes only for essential reasons (work, shopping, medical appointments)', which represents the essence of social distancing and was the central theme of the first UK lockdown. Answers to this variable take values between 1 (strongly oppose) and 5 (strongly support). Descriptively, $84 \%$ of respondents supported $(36 \%)$ or strongly supported $((48 \%)$ the lockdown, $10 \%$ neither supported or opposed, $4 \%$ opposed and $2 \%$ strongly opposed it. Figure 1 also shows that health-related worries were at the forefront of everyone's minds, when thinking about their circumstances, at the individual level, with variant but significant levels of concern in relation to economic and social parameters. These confirm, as in other countries, very high support for social distancing at the start of the crisis, indicating that the public had been convinced that the COVID-19 represented an existential threat that justifies the suspension of life as normal. 


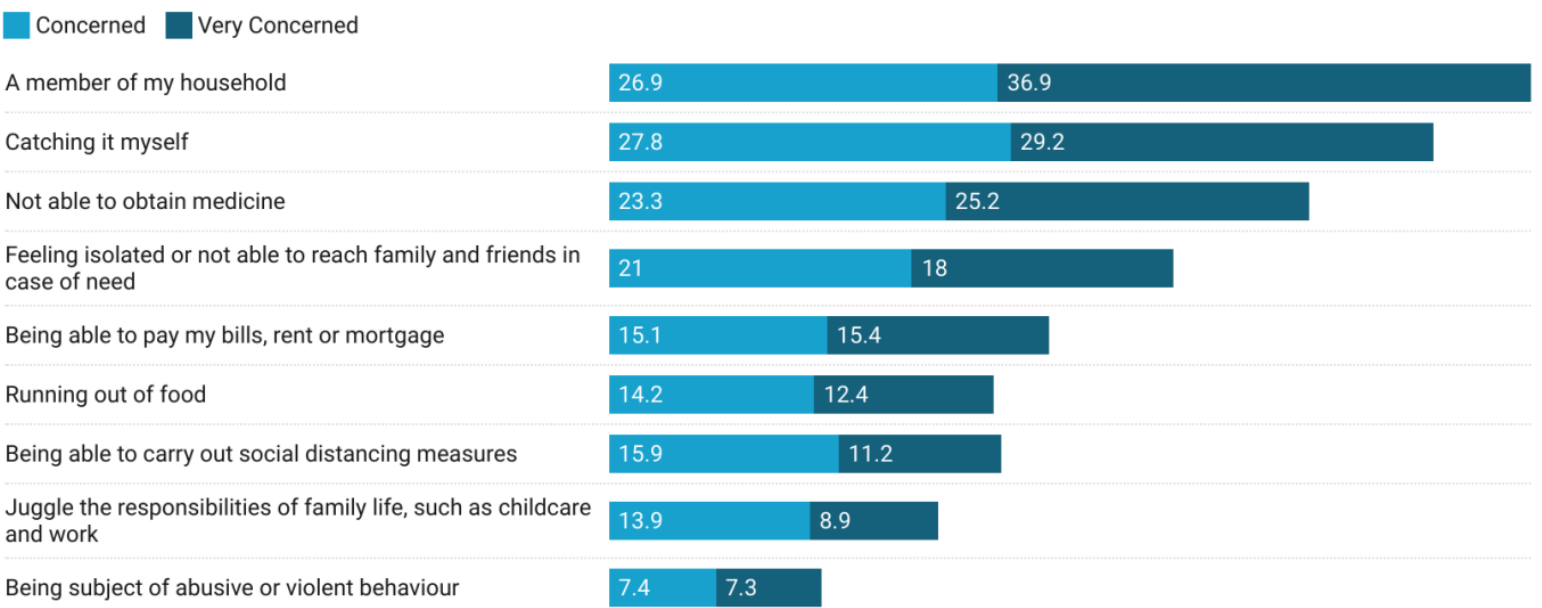

Figure 1. Main personal worries during the COVID-19 pandemic

Our data draws on an original survey conducted online by the polling organisation Deltapoll. The sample consisted of $\mathrm{N}=2,100$ British adults and is representative in terms of age, gender and region. With respect to gender, $47 \%$ of respondents are male $(\mathrm{N}=984)$ and $53 \%$ female $(\mathrm{N}=1,116) .10 \%$ of the sample self-identified as being Black, Asian, or from an ethnic minority (BAME) $(\mathrm{N}=224)$. The survey took place between April 10 and 15, 2020, while the UK was entering the third week of lockdown. The Prime Minister (PM) Boris Johnson was himself hospitalised after contracting COVID-19, which may have amplified the 'rally around the flag' effect by altering the emotional context. Public attitudes are particularly volatile to contextual changes, which typically accelerate during crises.

However, the timing of our survey allows us to provide a comprehensive account of the drivers of support for measures at the start of the crisis, by testing the explanatory value of health, socio-economic and political models, that have dominated current debates, compared to models centred around the four framing contests deriving from the crisis and security literatures. This is particularly facilitated by our rich and tailored-made questionnaire, which included measurements of the emerging key frames, identified in the thematic analysis. To test whether there are any issues of multicollinearity, we measured the pair-wise correlation among the explanatory variables for each of our models, and found them to not be very high. In cases where a pair of variables had a high correlation, we computed the VIF score measuring how much the variance of a regression coefficient can be inflated due to multicollinearity in the model. This reassures us that there are no issue of multicollinearity in any of our models (see Appendix).

\section{Framing Contests and Corresponding Public Attitudes}

This section employs thematic analysis to map public discourse around each of the four main framing contests identified in the theoretical literature, and the corresponding attitudes of the British public. The discussion here also serves to operationalise the variables and derive models that we use in the subsequent regression analyses, which seeks to identify the drivers of support for social distancing. 


\section{Severity and Nature}

On the day the lockdown was announced, Prime Minister (PM) Johnson claimed that COVID-19 posed the "biggest threat this country has faced for decades" (UK Government, 2020a). While the projected number of deaths did not feature in the government's discourse in this early stage of the pandemic, such estimates greatly varied among the scientific community. Experts placed the number of projected deaths between 500,000 (Kitching, 2020) - the worst-case scenario of the 'herd immunity' strategy - and 20,000 (Merrick, 2020a) - the best-case scenario. Indeed, since the very beginning, predominantly public health characteristics were ascribed to the threat. These were emphasised by Johnson referencing the rapidly growing number of "victims and fatalities", the continued "sacrifice of key workers", but also the need to defend the "functionality" of the NHS (UK Government, 2020b), which was the key element of the UK government's communications ('stay at home, protect the NHS, save lives'). Experts, such as the UK Chief Medical Officer, openly warned that under a worst-case scenario the NHS could run out of beds for COVID-19 victims (House of Commons, 2020).

However, different economic, social, and political aspects, which painted a complex threat, gradually started to feature in public discourse. The PM acknowledged that there was a serious, multi-faceted threat posed to the NHS, the economy and British lives (UK Government, 2020a), while a week earlier he had emphasised the need to defend the national economy (UK Government., 2020b). Experts warned that COVID-19 looked set to hike UK unemployment rates (Andrews, 2020), while the Office for Budget Responsibility (OBR), warned that the country faced a 'large (but hopefully temporary) shock to the economy' (Williams-Grut, 2020). The threat of social unrest made its appearance for the first time in public discourse in mid-March, when supermarkets' supply chains were put under pressure from stockpiling customers (Evans and Yorke, 2020). Lastly, the threat of Britain becoming a 'Police State' can be traced back to the days following the introduction of the 'Coronavirus Bill' on 25th March, which imposed unprecedented restrictions on civil liberties in peacetime (Jacobs, 2020).

\section{Projected number of COVID-19 deaths}

More than 500,000
Between 100,000 and 500,000
Between 50,000 and 100,000
Between 20,000 and 50,000
Between 10,000 and 20,000
Fewer than 10,000

More than 500,000

500,000

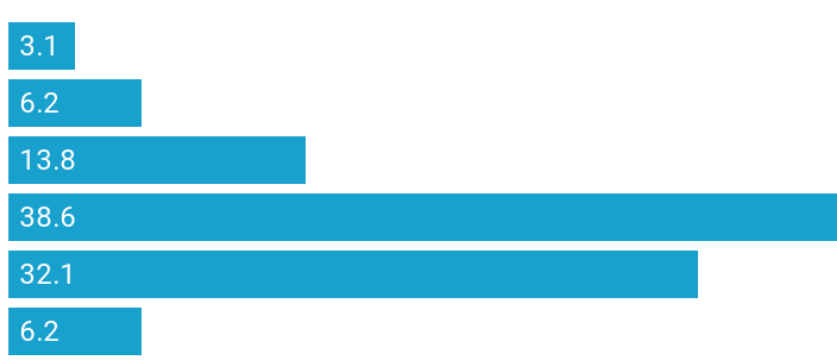




\section{Concern about the Pandemic in the UK leading to...(\%)}

Concerned

Very concerned

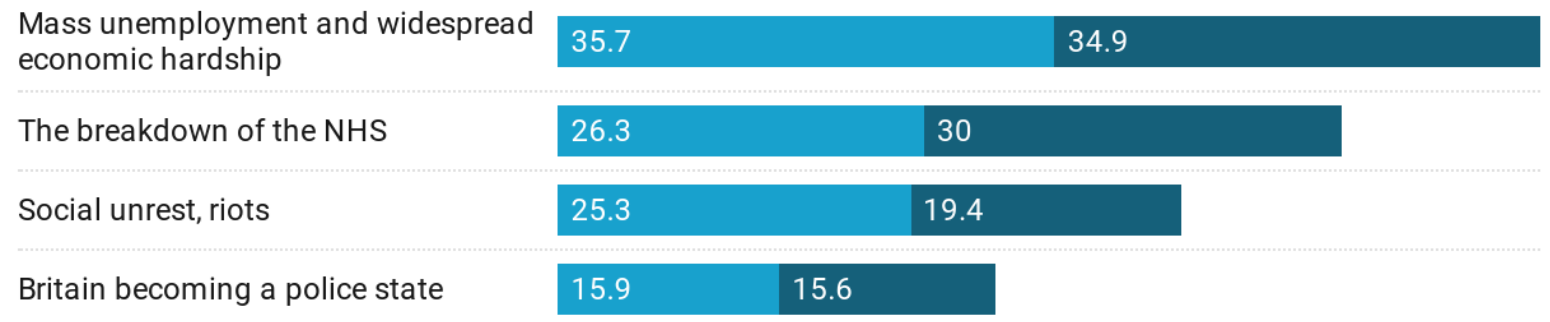

Figure 2. Severity and nature of threat

Descriptive survey results (Figure 2) show that, in general, the British public was in line with the more conservative estimates of the expected casualties, with $71 \%$ estimating that between 10,000 and 50,000 people would eventually die in the UK. At the time, 60,733 had tested positive for coronavirus and, of those hospitalised, 7,097 had died (Department of Health and Social Care, 2020). Perhaps surprisingly, more people were worried about economic implications (71\%), rather than the breakdown of the NHS $(56 \%)$ which featured heavily in the government's discourse. People worried far less about social unrest $(45 \%)$ or Britain becoming a police state $(32 \%)$, which were not promoted by mainstream political actors. In our analysis, the first model draws on these variables, relevant to the nature and severity of the threat.

\section{Blame Attribution}

The government also sought to diffuse responsibility and deflect blame for the crisis by continually referencing the global and shared threat that COVID-19 posed. For example, Johnson opened his lockdown speech by stating: "this country is not alone. All over the world we are seeing the devastating impact of this invisible killer... in other countries that also have fantastic health care systems, this is the moment of real danger" (UK Government, 2020a). As soon as Britain's death toll from the pandemic reached four figures in late March 2020, some government ministers, such as Michael Gove, started 'outsourcing' the blame for the UK's lack of mass testing on China. However, this frame was not very salient in our study overall, and certainly far less so in comparison to the US Administration (see Proctor, 2020).

The government directed attention towards personal responsibility, as the central positive incentive for the public to embrace the measures and one that can be traced to the country's historical legacy. One week before the introduction of the lockdown, the PM appealed to the public to unite like it had done in the past: "The country will get through this epidemic [sic], just as it has got through many tougher experiences before if we look out for each other and commit wholeheartedly to a full national effort... we are all enlisted" (UK Government, 2020b). These types of historical analogies - likening the situation to WW2 when British people were "all in it together" - were utilised regularly by the government. Personal responsibility was the dominant frame in the PM's speech 
announcing the lockdown, noting that: "in this fight we can be in no doubt that each and every one of us is ... obliged to join together and stay at home" (UK Government, 2020b).

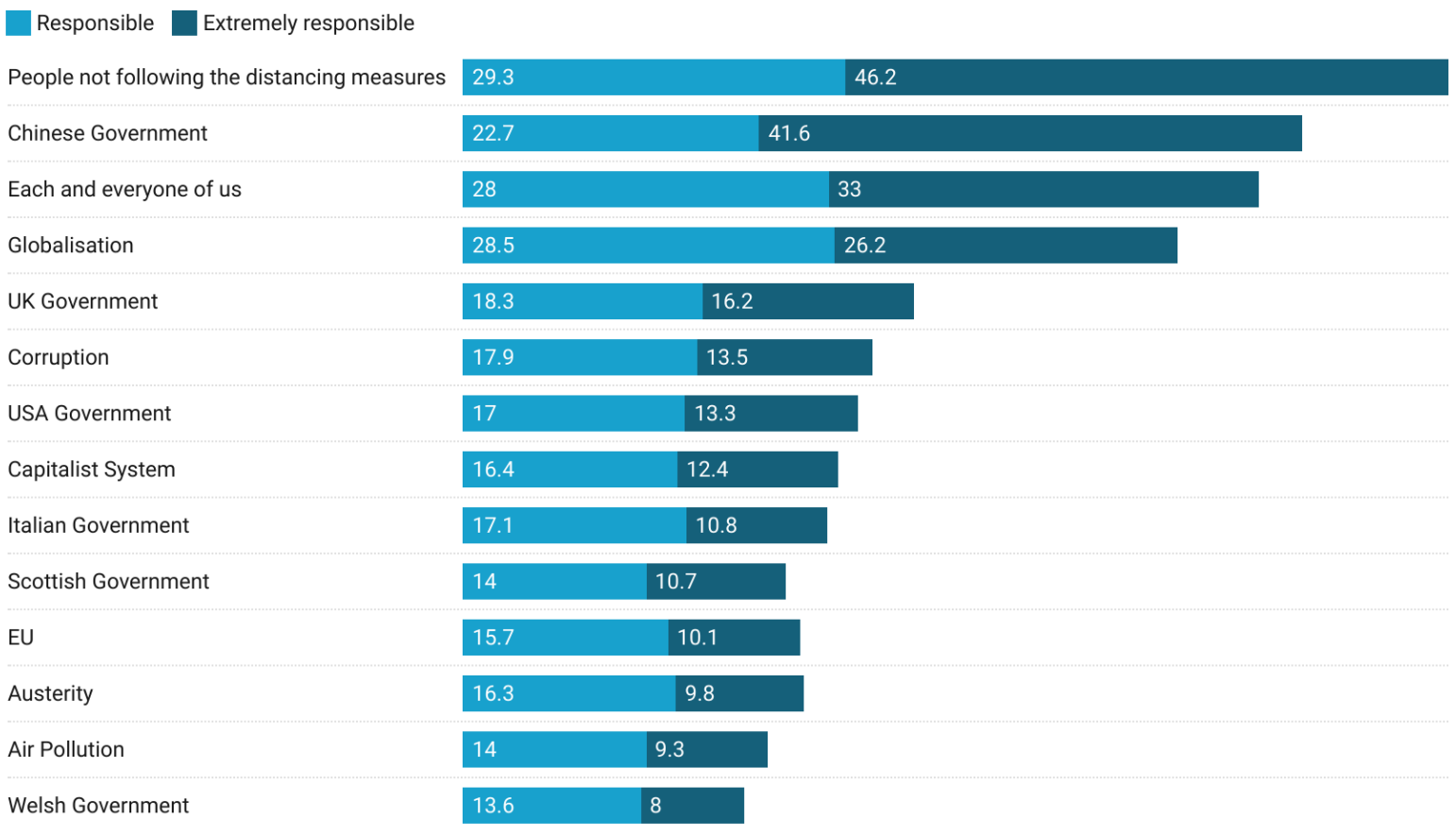

Figure 3. Blame attribution

Figure 3 shows that an overwhelming majority of the British public embraced the government's message to 'stay at home and save lives', identifying 'those that do not follow the social distancing measures' (75\%) as responsible for the outbreak. The complementary message that 'we are all in this together' also resonated with people, with $61 \%$ blaming 'each and everyone of us' for the pandemic. $65 \%$ of respondents blamed the Chinese government and $54 \%$ blamed globalisation, while only $35 \%$ blamed the UK government. This second framing contest is operationalised in our regression through a model that includes the top five factors that respondents identified as responsible for the spread of COVID-19 in the UK.

\section{Remedies and Trade-Offs}

The initial UK government response was to delay implementing social distancing measures. Reflecting a fatalistic frame, Johnson suggested on the 'This Morning' show on $5^{\text {th }}$ March that 'one of the theories is perhaps you could take it on the chin, take it all in one go, and allow the disease, as it were, to move through the population, without taking as many draconian measures. I think we need to strike a balance' (Simanowitz, 2020). Although Johnson never clearly advocated the 'take it on the chin' theory in public, this seems to have informed the government's 'herd immunity' response up until the announcement of school closures on $20^{\text {th }}$ March. Following public and international pressure, the UK government shifted from its delay phase to a contain phase, by introducing a number of mandated social-distancing requirements (Cabinet Office, 2020). 
Johnson encouraged the acceptance of these 'necessary' measures in order to reduce the number of "victims and fatalities, and protect the NHS" (UK Government, 2020a). The emphasis on what was at stake - saving lives and protecting a valued institution - implied that there was no alternative. The TINA frame was not challenged by any salient mainstream actor in the UK, with political leaders rallying around the flag in the face of a perceived existential threat. Indeed, opposing the measures would likely turn any challenger into a villain, as President Ford's political opponents found out during the 1976 US Swine Flu crisis (Boin et al., 2005). However, the 'crisis as opportunity' frame attempted to point to an alternative, potentially positive, side of the emerging harsh reality, by envisioning the possibility of a better tomorrow following these dark times. For example, in a widely read and circulated article in Financial Times in early April, novelist Arundhati Roy (2020) described COVID-19 as a portal, stating that '[h]istorically, pandemics have forced humans to break with the past and imagine their world anew. This one is no different'.

Indeed, the main frame that challenged TINA focused on criticising the UK government for not doing more, sooner, and in a fairer way at the start of the crisis. Partly in response, on March $20^{\text {th }}$ the government announced a comprehensive job retention furlough scheme, followed by a package for the self-employed workers on March $26^{\text {th }}$. Jeremy Corbyn (then leader of the Labour party) argued that the plans announced did not offer equal 'economic security' to everyone, with concerns for those in need of 'sick pay, selfemployed, those reliant on social security, renters, and others' (UK Labour Party, 2020). Corbyn also criticised the introduction of limited measures tailored to the NHS, such as the lack of 'PPE, testing and protection for social care workers', which threatened the health of 'key workers' (UK Parliament, 2020).

Disagree Neither disagree nor agree Agree

Women are more severely affected by the measures to deal with the pandemic compared to men

There Is nothing anybody can do to contain the spread of the coronavirus

The coronavirus crisis will accelerate rapid social and political transformations for the benefit of humanity

The economic burden of the government measures to contain the coronavirus is not distributed fairly to all citizens

The measures taken by the government to combat the coronavirus pandemic are necessary to prevent a major national catastrophe

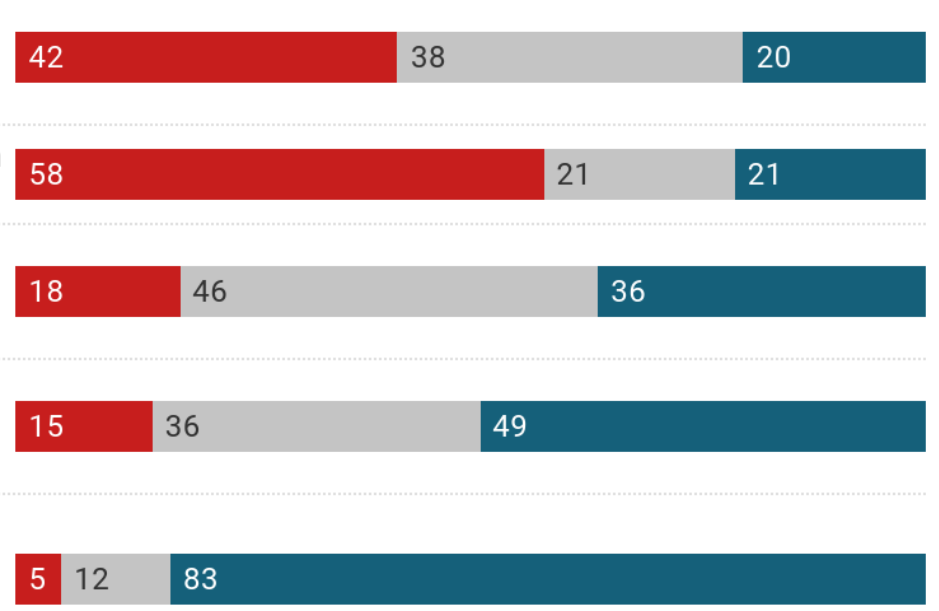

Figure 4. Public attitudes on key crisis frames

Operationalising this framing contest in our quantitative analysis required careful consideration. First, we asked participants a battery of questions that corresponded to the main frames deriving from the thematic analysis. Results are presented in Figure 4. The British public overwhelmingly accepted the government's TINA narrative (83\%), and 
strongly rejected the fatalistic frame (58\%), which seemed to have guided its initial response to the pandemic. At the same time, almost half of our respondents $(49 \%)$ embraced the message that the economic burden of the introduced measures is unevenly distributed, which was mainly advocated by the Leader of the Opposition. Less than half $(46 \%)$ embraced the 'crisis as opportunity' frame which, as noted above, was not central to Government messaging.

\section{Trade-off between public health and civil liberties considerations}

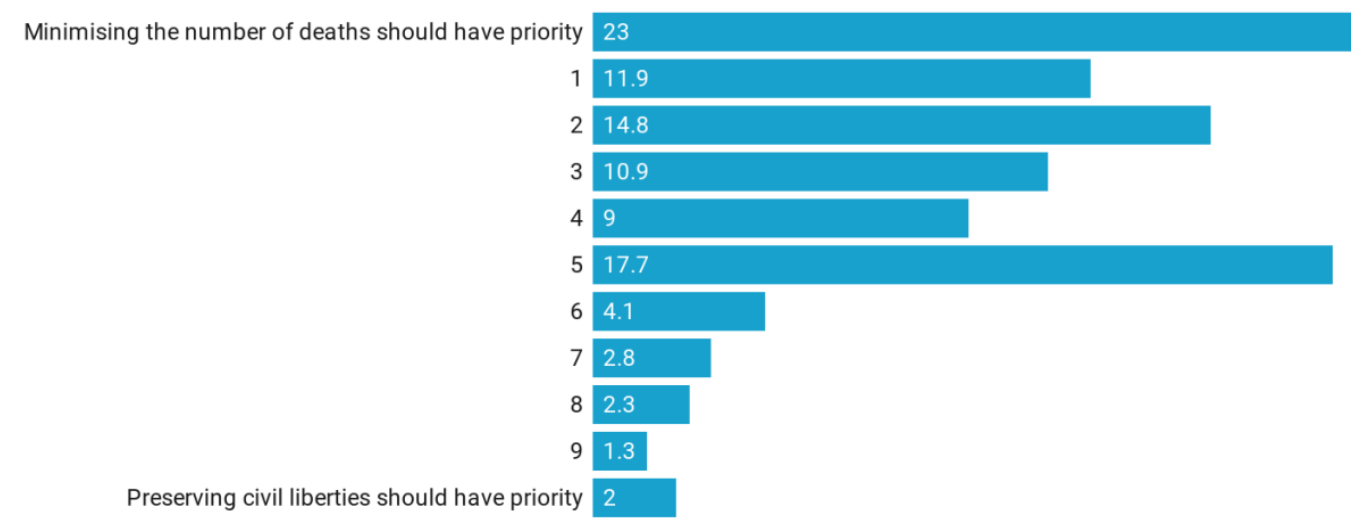

\section{Trade-off between public health and economic considerations}

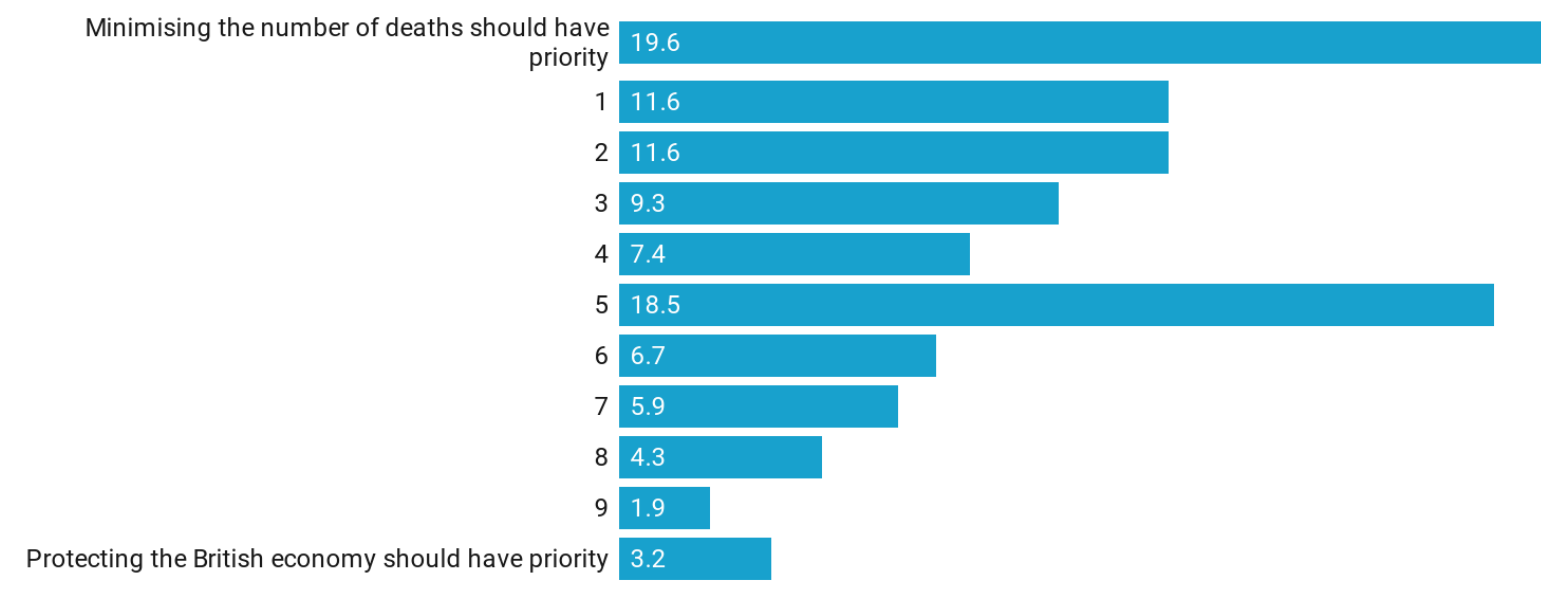

Figure 5. Public attitudes and perceived trade-offs

Second, we included two survey instruments to accurately capture public positioning on the policy trade-offs between public health and the economy or civil liberties. Figure 5 shows that the public was strongly in favour of prioritising public health over anything else, in line with the dominant political frames. More specifically, on a scale between these four positions, $59 \%$ and $70 \%$ of our respondents leaned towards minimising the number of deaths, whereas only $22 \%$ and $13 \%$ believed the economy and civil liberties, respectively, should take priority.

\section{Science and Scientific Expertise}

This last framing contest, which cuts across the previous three, is about who has the necessary expertise and authority to inform how we understand and respond to a pandemic, and who takes the blame if and when things go wrong. In mid-March, the 
WHO's director-general stated that every possible action needs to be taken: 'Not testing alone. Not contact tracing alone. Not quarantine alone. Not social distancing alone. Do it all' (Boseley, 2020). Along these lines, almost 400 UK-based scientists and medical experts signed an open letter in mid-March urging the government to implement more social distancing measures 'with immediate effect'. ${ }^{2}$ Expert advice is based on the assumption that governments are willing and capable of instigating policy change, although this advice is not always followed (Simanov et al., 2020). The government's testing strategy, and more specifically, the 'pivotal' decision on March $12^{\text {th }}$ to halt community testing and retreat to testing mainly within hospitals, attracted heavy criticism, with Public Health England and the Department for Health and Social Care blaming each other (Merrick, 2020b). Perhaps in an attempt to deflect the blame, both the PM and Foreign Secretary have frequently stressed that the government was following the guidelines of 'world-leading scientists' since the very beginning (UK Government 2020a; 2020c). Science also provides answers as to the question as to what caused the pandemic, an issue that did not attract attention in public debates in the UK but featured in conspiracy theories and in the discourse of other leaders, with US President Trump, for example, claiming to have seen undisclosed evidence that COVID-19 escaped from a laboratory in Wuhan, China. ${ }^{3}$

Not sure $\square$ Scientific Causes of Pandemic $\square$ Conspiracy Causes of Pandemic

\begin{tabular}{l|l} 
Was developed intentionally in a lab & 15.3 \\
\hline Was made accidentally in a lab & 7.1 \\
\hline Doesn't really exist & 10.6 \\
\hline Came about naturally & 15.3 \\
\hline It was caused by human living habits & 38.1 \\
\hline It came from animals & 12.7 \\
\hline Not sure &
\end{tabular}

Figure 6. Perceived causes of the pandemic

We asked participants to indicate their trust in scientists advising the government using a scale that goes from 0 (no trust at all) to 10 (complete trust). The median values for trust is 7 , indicating a relatively high trust in them. We also asked them to indicate, from what they heard or read, what they thought were the causes of the pandemic. Figure 6 shows that a majority $(64 \%)$ agree with scientific explanations, but $24 \%$ endorse conspiracy theories, and $13 \%$ are unsure. In terms of broader attitudes to science, $27 \%$ of respondents considered that science does more harm than good, while $25 \%$ considered that we believe too often in science, and not enough in feelings. Attitudes to climate change are also indicative of scientific views, with $51 \%$ believing it is completely true that

\footnotetext{
2 See 'Public request to take stronger measures of social distancing across the UK with immediate effect', available at:

http://maths.qmul.ac.uk/ vnicosia/UK_scientists statement on coronavirus measures.pdf.

See https://www.ibtimes.com/coronavirus-origin-trump-has-seen-evidence-covid-19-camewuhan-lab-2968344
} 
climate change will, if unchecked, do great damage to the earth's environment and only $5 \%$ believe it completely untrue. To operationalise this framing contest, our corresponding model includes the above three variables about attitudes to science and the two competing explanations about the cause of the pandemic.

\section{The Drivers of Support for Social Distancing}

Academic and policy attention, thus far, has mainly pointed towards socio-economic factors to predict support for social distancing, which our data allows us to test, before turning our attention to the crisis framing dynamics. In Table 1, we present a comprehensive socio-economic model, constituted by separate health, economic and political sub-models. The coefficients obtained in the socio-economic model are largely as expected from the literature. First, the prevention paradox is confirmed, with people already diagnosed with COVID-19 statistically less likely to support the lockdown. Health vulnerability and concern about yourself or a member of your family catching the virus increases support for measures, with health variables shown robustness to the addition of economic and political variables, as the last column in Table 1 shows. Second, the economic model confirms that people with responsibilities of family life and those that feel economically more vulnerable than others are significantly less likely to support the measures. Concerns over paying bills and prospective evaluations about personal and national economic circumstances do not impact on attitudes. Third, people who consider that they can personally influence whether they get infected, are better informed about the pandemic crisis and trust the British government are significantly more likely to support the measures - evaluations about its performance in managing the pandemic make no difference, at this early stage. Untypically, it is left, not right-wing ideology that increases public support for draconian measures in the face of a public health emergency, which requires sacrifices for the collective good. This, and questions about the perceived efficacy, not only of individuals, but also of specific policy measures (e.g. wearing masks) should be fruitfully explored in future research. 
Table 1. Socio-economic predictors of support for social distancing

\begin{tabular}{|c|c|c|c|c|}
\hline & $\begin{array}{c}\text { (1) } \\
\text { Health }\end{array}$ & $\begin{array}{c}(2) \\
\text { Economic }\end{array}$ & $\begin{array}{c}\text { (3) } \\
\text { Political }\end{array}$ & $\begin{array}{l}\text { (4) } \\
\text { All }\end{array}$ \\
\hline Previously diagnosed with COVID-19 & $\begin{array}{l}-0.03^{*} \\
(0.02)\end{array}$ & & & $\begin{array}{l}-0.03^{*} \\
(0.02)\end{array}$ \\
\hline Health vulnerability & $\begin{array}{c}0.09 * * * \\
(0.02)\end{array}$ & & & $\begin{array}{c}0.06 * * * \\
(0.02)\end{array}$ \\
\hline Concern: Catching it myself & $\begin{array}{c}0.09 * * * \\
(0.02)\end{array}$ & & & $\begin{array}{l}0.06^{* *} \\
(0.02)\end{array}$ \\
\hline Concern: A member of the family becoming infected & $\begin{array}{l}0.06^{* *} \\
(0.02)\end{array}$ & & & $\begin{array}{c}0.06 * * \\
(0.02)\end{array}$ \\
\hline Concern: Not able to obtain medicine/ treatment & $\begin{array}{l}-0.02 \\
(0.02)\end{array}$ & & & $\begin{array}{l}0.04 * \\
(0.02)\end{array}$ \\
\hline Egocentric prospective economic evaluations & & $\begin{array}{c}0.03 \\
(0.03)\end{array}$ & & $\begin{array}{c}0.02 \\
(0.03)\end{array}$ \\
\hline Sociotropic prospective economic evaluations & & $\begin{array}{c}0.02 \\
(0.02)\end{array}$ & & $\begin{array}{c}0.02 \\
(0.02)\end{array}$ \\
\hline Economic vulnerability compared to others & & $\begin{array}{c}-0.09 * * * \\
(0.02)\end{array}$ & & $\begin{array}{c}-0.05^{* *} \\
(0.02)\end{array}$ \\
\hline $\begin{array}{l}\text { Concern: Juggling the responsibilities of family life } \\
\text { (childcare, work) }\end{array}$ & & $\begin{array}{c}-0.07 * * * \\
(0.02)\end{array}$ & & $\begin{array}{c}-0.10^{* * *} \\
(0.02)\end{array}$ \\
\hline Concern: Being able to pay my bills, rent or mortgage & & $\begin{array}{c}0.02 \\
(0.02)\end{array}$ & & $\begin{array}{l}-0.02 \\
(0.02)\end{array}$ \\
\hline Informed about COVID19 & & & $\begin{array}{c}0.08 * * * \\
(0.01)\end{array}$ & $\begin{array}{c}0.07 * * * \\
(0.01)\end{array}$ \\
\hline Self-efficacy: personally influence whether infected & & & $\begin{array}{c}0.05^{* * *} \\
(0.01)\end{array}$ & $\begin{array}{c}0.05 * * * \\
(0.01)\end{array}$ \\
\hline Trust the UK government & & & $\begin{array}{c}0.06 * * * \\
(0.01)\end{array}$ & $\begin{array}{c}0.06 * * * \\
(0.01)\end{array}$ \\
\hline Performance of the UK government during pandemic & & & $\begin{array}{c}0.00 \\
(0.02)\end{array}$ & $\begin{array}{l}-0.01 \\
(0.02)\end{array}$ \\
\hline Ideology (left) & & & $\begin{array}{c}-0.04 * * * \\
(0.01)\end{array}$ & $\begin{array}{c}-0.03 * * * \\
(0.01)\end{array}$ \\
\hline Female & $\begin{array}{l}0.10^{* *} \\
(0.04)\end{array}$ & $\begin{array}{c}0.13 * * * \\
(0.04)\end{array}$ & $\begin{array}{c}0.13 * * * \\
(0.04)\end{array}$ & $\begin{array}{l}0.10^{* *} \\
(0.04)\end{array}$ \\
\hline Essential worker role & $\begin{array}{l}-0.10^{*} \\
(0.04)\end{array}$ & $\begin{array}{l}-0.05 \\
(0.04)\end{array}$ & $\begin{array}{l}-0.10^{*} \\
(0.04)\end{array}$ & $\begin{array}{l}-0.08 \\
(0.04)\end{array}$ \\
\hline Age (log) & $\begin{array}{c}0.54 * * * \\
(0.05)\end{array}$ & $\begin{array}{c}0.51 * * * \\
(0.05)\end{array}$ & $\begin{array}{c}0.41 * * * \\
(0.05)\end{array}$ & $\begin{array}{c}0.27 * * * \\
(0.05)\end{array}$ \\
\hline Disabled & $\begin{array}{c}0.06 \\
(0.05)\end{array}$ & $\begin{array}{c}0.05 \\
(0.05)\end{array}$ & $0.07(0.05)$ & $\begin{array}{c}0.07 \\
(0.05)\end{array}$ \\
\hline LGBT+ & $\begin{array}{l}-0.09 \\
(0.07)\end{array}$ & $\begin{array}{l}-0.10 \\
(0.07)\end{array}$ & $-0.13(0.07)$ & $\begin{array}{l}-0.12 \\
(0.07)\end{array}$ \\
\hline Ethnic minority & $\begin{array}{c}-0.22 * * * \\
(0.06)\end{array}$ & $\begin{array}{c}-0.18^{* *} \\
(0.06)\end{array}$ & $\begin{array}{c}-0.16^{* *} \\
(0.06)\end{array}$ & $\begin{array}{l}-0.11 \\
(0.06)\end{array}$ \\
\hline (Intercept) & $\begin{array}{c}1.78 * * * \\
(0.27)\end{array}$ & $\begin{array}{c}2.59 * * * \\
(0.28)\end{array}$ & $\begin{array}{c}1.77 * * * \\
(0.26)\end{array}$ & $\begin{array}{c}2.00 * * * \\
(0.28)\end{array}$ \\
\hline $\mathbf{R}^{2}$ & 0.13 & 0.11 & 0.19 & 0.23 \\
\hline Adj. $\mathbf{R}^{2}$ & 0.12 & $\mathbf{0 . 1 0}$ & 0.18 & 0.22 \\
\hline Num. obs. & 2100 & 2100 & 2100 & 2100 \\
\hline RMSE & 0.85 & 0.86 & 0.82 & 0.80 \\
\hline
\end{tabular}


Overall, the adjusted $\mathrm{R}^{2}$ in Table 1 indicates that $12 \%$ of the variation of the dependent variable is explained by health factors, $10 \%$ by economic and $18 \%$ by political considerations. Taken together, the socio-economic model explains only $22 \%$ of the variation in support for the lockdown, indicating that other factors also play an important role in shaping support for social distancing measures. Our expectation is that framing may account for some of the missing variance. Table 2 presents a Crisis Management composite model, consisted of four sub-models, each corresponding to the four framing contests discussed earlier.

Starting with the Nature and Severity model, coefficients show that people who see the crisis as a threat that may break the NHS or increase unemployment, are significantly more likely to support the measures. On the other hand, those concerned about social unrest or Britain becoming a police state, are significantly more likely to oppose them. Interestingly, concern over the NHS is not a robust predictor of public attitudes, as the last column in Table 2 shows, which indicates that a central element in the government's crisis communications failed to register with the public. The number of expected deaths, as a proxy for the crisis' objective severity, has no impact on public attitudes on the lockdown, as hypothesised. Overall, the adjusted $\mathrm{R}^{2}$ of the model indicates that it explains $17 \%$ of the variance of our dependent variable.

Results from the Blame Attribution model indicate that personal responsibility allocated to people not following social distancing has the strongest positive effect in explaining support for social distancing measures. Individuals who assign high levels of blame to each member of society also show significantly more support for social distancing measures. Unsurprisingly, those respondents assigning higher levels of blame to the UK government are less likely to support social distancing, but this finding is not robust to the addition of other explanations and control variables. On the other hand, exogenising blame to the Chinese government or globalisation, does not impact on public attitudes, arguably because such frames were neither as salient nor as weaponised in the UK, as was the case in the United States. Overall, these results suggest that levels of support are higher among individuals who shifted the government's responsibility to the individuals in society. The $\mathrm{R}^{2}$ indicates that the model explains $19 \%$ of the variation of the dependent variable.

The third framing contest (the remedies and perceived trade-offs required to contain the pandemic) holds, by far, the strongest explanatory power, explaining $38 \%$ of the variance in our dependent variable. Our regression analysis shows that the perceived necessity of measures plays the biggest role in driving support, while the fairness frame does not make any statistical difference, replicating findings from the Eurozone crisis (Karyotis and Rüdig, 2015). Those who see the crisis as an opportunity are significantly more likely to support social distancing measures. Finally, the 'fatalist' frame decreases the level of support for social distancing measures. Political elites who advocated for 'herd immunity' on the basis of convincing the public that we will all get the disease and there is nothing we can do to prevent it could, in practice, be responsible for a decrease in support for social distancing measures. When it comes to the perceived trade-offs, we find that people are less likely to support social distancing measures when they consider 
Table 2. Crisis management theory predictors of support for social distancing

\begin{tabular}{|c|c|c|c|c|c|}
\hline & $\begin{array}{c}\text { (1) } \\
\text { Severity } \\
\text { and Nature }\end{array}$ & $\begin{array}{c}\text { (2) } \\
\text { Blame } \\
\text { Attribution }\end{array}$ & $\begin{array}{c}\text { (3) } \\
\text { Remedies } \\
\text { and Trade- } \\
\text { Offs }\end{array}$ & $\begin{array}{c}(4) \\
\text { Science } \\
\text { and } \\
\text { Scientific } \\
\text { Expertise }\end{array}$ & $\begin{array}{l}\text { (5) } \\
\text { All }\end{array}$ \\
\hline Severity: expected casualties & $\begin{array}{l}-0.01 \\
(0.02)\end{array}$ & & & & $\begin{array}{l}-0.01 \\
(0.01)\end{array}$ \\
\hline Concern: Breakdown NHS & $\begin{array}{c}0.11 * * * \\
(0.02)\end{array}$ & & & & $\begin{array}{c}0.03 \\
(0.02)\end{array}$ \\
\hline Concern: Mass unemployment & $\begin{array}{c}0.19 * * * \\
(0.02)\end{array}$ & & & & $\begin{array}{c}0.07 * * * \\
(0.02)\end{array}$ \\
\hline Concern: Social unrest & $\begin{array}{c}-0.07^{* *} \\
(0.02)\end{array}$ & & & & $\begin{array}{c}-0.05^{* *} \\
(0.02)\end{array}$ \\
\hline $\begin{array}{l}\text { Concern: Britain becoming a police } \\
\text { state }\end{array}$ & $\begin{array}{c}-0.16 * * * \\
(0.02)\end{array}$ & & & & $\begin{array}{c}-0.04 * * \\
(0.02)\end{array}$ \\
\hline Blame: The UK government & & $\begin{array}{l}-0.03^{*} \\
(0.02)\end{array}$ & & & $\begin{array}{l}-0.02 \\
(0.01)\end{array}$ \\
\hline Blame: The Chinese government & & $\begin{array}{c}0.02 \\
(0.02)\end{array}$ & & & $\begin{array}{l}-0.01 \\
(0.01)\end{array}$ \\
\hline Blame: People not following measures & & $\begin{array}{c}0.26^{* * *} \\
(0.02)\end{array}$ & & & $\begin{array}{c}0.08 * * * \\
(0.02)\end{array}$ \\
\hline Blame: Globalisation & & $\begin{array}{c}0.02 \\
(0.02)\end{array}$ & & & $\begin{array}{c}0.02 \\
(0.01)\end{array}$ \\
\hline Blame: Each and every one of us & & $\begin{array}{l}0.06 * * \\
(0.02)\end{array}$ & & & $\begin{array}{l}0.00 \\
(0.02)\end{array}$ \\
\hline TINA frame: Measures Necessary & & & $\begin{array}{c}0.44 * * * \\
(0.02)\end{array}$ & & $\begin{array}{c}0.36 * * * \\
(0.02)\end{array}$ \\
\hline Measures Unfair & & & $\begin{array}{c}0.02 \\
(0.02)\end{array}$ & & $\begin{array}{c}0.01 \\
(0.02)\end{array}$ \\
\hline $\begin{array}{l}\text { Trade-off 1: Economy priority over } \\
\text { health }\end{array}$ & & & $\begin{array}{c}-0.03 * * * \\
(0.01)\end{array}$ & & $\begin{array}{c}-0.03 * * * \\
(0.01)\end{array}$ \\
\hline $\begin{array}{l}\text { Trade-Off } 2 \text { : Health priority over civil } \\
\text { liberties }\end{array}$ & & & $\begin{array}{c}0.03 * * * \\
(0.01)\end{array}$ & & $\begin{array}{c}0.02 * * * \\
(0.01)\end{array}$ \\
\hline Crisis as opportunity Frame & & & $\begin{array}{l}0.04 * \\
(0.02)\end{array}$ & & $\begin{array}{l}0.04^{*} \\
(0.02)\end{array}$ \\
\hline Fatalism Frame: Nothing we can do & & & $\begin{array}{c}-0.07 * * * \\
(0.01)\end{array}$ & & $\begin{array}{l}-0.03 * \\
(0.02)\end{array}$ \\
\hline Conspiracy Cause of COVID-19 & & & & $0.04(0.06)$ & $\begin{array}{l}-0.02 \\
(0.05)\end{array}$ \\
\hline Scientific Cause of COVID19. & & & & $0.04(0.06)$ & $\begin{array}{l}-0.02 \\
(0.05)\end{array}$ \\
\hline $\begin{array}{l}\text { Science scepticism: faith, feelings } \\
\text { more important }\end{array}$ & & & & $\begin{array}{l}-0.05^{* *} \\
(0.02)\end{array}$ & $\begin{array}{l}-0.03 \\
(0.02)\end{array}$ \\
\hline $\begin{array}{l}\text { Trust in the scientists advising the UK } \\
\text { government }\end{array}$ & & & & $\begin{array}{c}0.10^{* * *} \\
(0.01)\end{array}$ & $\begin{array}{l}0.03 * * \\
(0.01)\end{array}$ \\
\hline $\begin{array}{l}\text { Modern science does more good than } \\
\text { harm }\end{array}$ & & & & $0.02(0.02)$ & $\begin{array}{c}0.02 \\
(0.01)\end{array}$ \\
\hline Climate change scepticism & & & & $\begin{array}{c}-0.18 * * * \\
(0.03)\end{array}$ & $\begin{array}{l}-0.03 \\
(0.03)\end{array}$ \\
\hline Female & $\begin{array}{l}0.10^{* *} \\
(0.04)\end{array}$ & $\begin{array}{c}0.05 \\
(0.04)\end{array}$ & $\begin{array}{c}0.01 \\
(0.03)\end{array}$ & $\begin{array}{c}0.13^{* * *} \\
(0.04)\end{array}$ & $\begin{array}{c}0.00 \\
(0.03)\end{array}$ \\
\hline Key worker role & $\begin{array}{l}-0.07 \\
(0.04)\end{array}$ & $\begin{array}{c}-0.09^{*} \\
(0.04)\end{array}$ & $\begin{array}{l}-0.02 \\
(0.04)\end{array}$ & $\begin{array}{l}-0.06 \\
(0.04)\end{array}$ & $\begin{array}{l}-0.03 \\
(0.04)\end{array}$ \\
\hline
\end{tabular}




\begin{tabular}{|l|c|c|c|c|c|}
\hline Age (log) & $0.52^{* * *}$ & $0.48^{* * *}$ & $0.20^{* * *}$ & $0.47 * * *$ & $\mathbf{0 . 1 8 * * *}$ \\
& $(0.05)$ & $(0.05)$ & $(0.05)$ & $(0.05)$ & $(0.05)$ \\
\hline Disabled & 0.06 & 0.01 & 0.00 & 0.08 & 0.01 \\
& $(0.05)$ & $(0.05)$ & $(0.05)$ & $(0.05)$ & $(0.04)$ \\
\hline LGBT+ & -0.08 & -0.07 & -0.01 & -0.10 & -0.01 \\
& $(0.07)$ & $(0.07)$ & $(0.06)$ & $(0.07)$ & $(0.06)$ \\
\hline Ethnic minority & $-0.21^{* * *}$ & $-0.21^{* * *}$ & $-0.15^{* *}$ & $-0.16^{* *}$ & $-0.13^{*}$ \\
& $(0.06)$ & $(0.06)$ & $(0.05)$ & $(0.06)$ & $(0.05)$ \\
\hline Intercept) & $2.02^{* * *}$ & $1.46^{* * *}$ & $1.68^{* * *}$ & $2.18^{* * *}$ & $1.53^{* * *}$ \\
& $(0.27)$ & $(0.26)$ & $(0.24)$ & $(0.28)$ & $(0.26)$ \\
\hline $\mathbf{R}^{2}$ & 0.17 & 0.20 & 0.38 & 0.18 & 0.41 \\
\hline Adj. $\mathbf{R}^{2}$ & $\mathbf{0 . 1 7}$ & $\mathbf{0 . 1 9}$ & $\mathbf{0 . 3 8}$ & $\mathbf{0 . 1 8}$ & $\mathbf{0 . 4 0}$ \\
\hline Num. obs. & 2100 & 2100 & 2100 & 2100 & 2100 \\
\hline RMSE & 0.83 & 0.82 & 0.72 & 0.82 & 0.71 \\
\hline & & & Signif. codes: * $\mathbf{0 . 0 5}$ ** & $\mathbf{0 . 0 1}$ & *** 0.001 \\
\hline
\end{tabular}

that the state of the economy or the protection of civil liberties should be prioritised over the health of the population. All these variables are robust to the addition of other explanations and control variables, as shown in the last column of Table 2.

Lastly, the scientific model explains $18 \%$ of the variance of our dependent variable, more than both the health and economic models. Contrary to expectations, perceptions about the causes of the pandemic, scientific or conspiracy ones, have no impact on public support for social distancing, likely because they were largely absent in UK debates, unlike the USA. Our results also show that climate change sceptics and those privileging faith over science are significantly less likely to support government measures. Once control variables and other framing contests are taken into account, however, the only variable from this model that remains robust in its effect is whether people trust the scientists advising the UK government: those that do so, are significantly more likely to support the social distancing measures, as hypothesised.

As shown in Tables 1 and 2, the demographics of age, gender, and ethnicity produce consistent and statistically significant results that are in line with the expectations derived from the literature. Older people and females are more likely to support government measures. In contrast to this, people coming from an ethnic minority background are significantly less likely to support the measures. Interestingly, key workers were less supportive of social distancing measures, but the effect loses its significance in some models, indicating that variation in support for the lockdown from key workers is contingent on other factors. On the whole, our results confirm the central importance of framing in explaining support for social distancing measures. The crisis management framing comprehensive model has an adjusted $\mathrm{R}^{2}$ twice the size of that of the socio-economic model ( 0.40 and 0.20 , respectively), indicating that the crisis management framing offers a better fit than socio-economic factors to explain the support for the government measures against COVID-19. This is an important finding that highlights the previously unexplored significance of framing contests around the nature, severity and appropriate response to a crisis in shaping public attitudes, within a specific national context.

\section{Conclusion}


This article has sought to determine what drives public support for social distancing measures. While we have confirmed that the socio-economic factors identified in the existing literature matter, we demonstrate that framing contests and the ability of the government to produce and communicate a coherent crisis narrative matter much more. Based on a mixed methods approach involving thematic analysis of four key framing contests and a representative survey of the UK population conducted in the early stages of the pandemic, we find that framing explains more than twice the variance in public support. Our analysis allowed us to examine the relative effects of competitive frames on attitudes.

Our results show that the public mainly looked to the Government as the main source of information on the pandemic and that the frames promoted by government resonated with the public more than frames promoted by other sources. In the early stage of the crisis the centrepiece of Government communications was that 'there is no alternative' to the adoption of social distancing measures, and this is by far the strongest driver of support. The government was also successful in its messaging about the need to take personal responsibility for the 'greater good', with the public assigning blame for the spread of the virus to people who we weren't following the measures. While the public may be influenced by external debates as well, as indicated by the high percentage of people blaming the Chinese Government, this frame was not salient in UK debates and had no impact on support for measures. This further highlights the central importance of how the UK Government narrated the crisis as it unfolded. Another key component of the Government's messaging was that it was 'following the science' and our analysis indicates that trust in the scientists advising the Government was an important factor in explaining support for social distancing measures.

This doesn't mean that the Government 'won' every framing contest. A key message about the need to protect the NHS did not drive support for social distancing measures. The 'fatalist' and 'crisis as opportunity' frames played a role in driving opposition and support respectively, although the 'fairness' frame deployed by the Opposition had no effect. Unsurprisingly, people were less likely to support social distancing measures when they considered that the economy or the protection of civil liberties should be prioritised over public health. These latter two frames have become more prominent since this research was conducted and there has been some decline in support for the British government's handling of the crisis. There have also been some small protests about the measures from 'lockdown sceptics' and 'anti-vaxxers' which, along with a greater degree of contestation between the Government and scientists, has resulted in an increasingly crowded communicative space.

These developments strengthen the case for further research on how elite frames and public attitudes develop throughout a crisis, to fully understand the dynamics of crisis communication. Utilising mixed methods is crucial if we are to examine both the salience and resonance of these frames. Moreover, they further highlight the importance of coherent and effective crisis communication for ensuring public support for social distancing. At the time of writing the UK Government has just reintroduced a national lockdown after a period of regional and 'tiered' approaches to the implementation of crisis 
What Drives Support for Social Distancing? Pandemic Politics, Securitisation and Crisis Management in Britain

measures, which did not do enough to reduce infection rates. Without adequate attention to framing dynamics, it will be difficult for the UK Government (or other governments) to maintain support for measures. 


\section{Bibliography}

Abbasi, K. (2020). Covid-19: politicisation, "corruption," and suppression of science. British Medical Journal, 371.

Adamides, C. (2020). Securitization and Desecuritization Processes in Protracted Conflicts. Springer International Publishing.

Allcott, H., et al. (2020). Polarization and public health: partisan differences in social distancing during the coronavirus pandemic. NBER Working Paper No. w26946.

Andrews, K. (2020). Coronavirus looks set to hike UK unemployment rates - and skyrocket them in the Eurozone', The Spectator 24 March.

Benford, R.D. and Snow, D.A. (2000). Framing processes and social movements: an overview and assessment. Annual Review of Sociology 26(1): 611-639.

Bengtsson, L. and Rhinard, M. (2019). Securitisation across borders: the case of 'health security' cooperation in the European Union. West European Politics 42(2): 346368.

Berling, T.V. (2011). Science and securitization. Security Dialogue 42(4-5): 385-397.

Boin, A., and 't Hart, P. (2003). Public leadership in times of crisis: mission impossible? Public Administration Review 63(5): 544-553.

Boin, A., et al. (2005). The politics of crisis management: leadership under pressure. Cambridge: Cambridge University Press.

Boin, A., et al. (2009). Crisis exploitation: political and policy impacts of framing contests. Journal of European Public Policy 16(1): 81-106.

Boseley, S. (2020). WHO urges countries to 'track and trace' every COVID-19 case. The Guardian 13 March.

Bovens, M. et al. (1999). The politics of blame avoidance: defensive tactics in a Dutch crime-fighting fiasco. In: $\mathrm{H}$. Anheier (ed.) When Things Go Wrong. Thousand Oaks, CA: Sage Publications.

Boyatzis, R. (1998). Transforming qualitative information: Thematic analysis and code development. Thousand Oaks, CA: Sage.

Boycott-Owen, M., et al. (2020). Coronavirus: Boris Johnson puts UK in lockdown as death toll reaches 55. The Telegraph 16 March.

Brandström, A. and Kuipers, S. (2003) From 'normal incidents' to political crises: understanding the selective politicization of policy failures. Government and Opposition 38(3): 279-305.

Bricese, G., et al. (2020) Compliance with covid-19 social-distancing measures in Italy: the role of expectations and duration. IZA Discussion Papers No. 13092.

Bronk, R. (2021) The art of following the science. LSE EUROPP blog 18 January, https://blogs.Ise.ac.uk/europpblog/2021/01/18/the-art-of-following-the-science/

Bull, M.J. (2020) Beating COVID-19: the problem with national lockdowns. LSE EUROPP blog 26 March, https://blogs.Ise.ac.uk/europpblog/2020/03/26/beatingcovid-19-the-problem-with-national-lockdowns/

Buzan, B., et al. (1998) Security: A New Framework for Analysis (Boulder, CO: Lynne Rienner).

Cabinet Office. (2020). Staying alert and safe (social distancing). https://www.gov.uk/government/publications/staying-alert-and-safe-socialdistancing

Crabtree, B. and Miller, W. (1999). 'A template approach to text analysis: Developing and using codebooks'. In B. Crabtree and W. Miller (Eds.), Doing qualitative research. Newbury Park, CA: Sage, 163-177.

Cruz, C. (2000). Identity and Persuasion: how nations remember their pasts and make their futures. World Politics 52(3): 275-312. 
Curley, M.G. and Herington, J. (2011). The securitisation of avian influenza: international discourses and domestic politics in Asia. Review of International Studies 37(1): 141-166.

Daly J, Kellehear A, and Gliksman M. (1997). The public health researcher: $A$ methodological approach. Oxford: Oxford University Press.

Davies, S.E. (2008) Securitizing infectious disease. International Affairs 84(2): 295-313.

Druckman, J. N. (2001). On the limits of framing effects: Who can frame? Journal of Politics 63(4): 1041-1066.

Dunt, I. (2020). Coronavirus bill: the biggest expansion in executive power we've seen in our lifetime. politics.co.uk 18 March, https://www.politics.co.uk/blogs/2020/03/18/coronavirus-bill-the-biggestexpansion-in-executive-power-we

Entman, R. M. (1993). Framing: Towards clarification of a fractured paradigm. Journal of Communication 43: 51-58.

Eriksson, J. (2020). Threat Framing. In Oxford Research Encyclopedia of Politics.

Evans, M. and Yorke, H. (2020). Supermarkets call for police protection amid fears of rioting. The Telegraph 18 March.

Ghosh, P. (2020). Coronavirus: Some scientists say UK virus strategy is 'risking lives'. 14 March, available at https://www.bbc.co.uk/news/science-environment51892402

't Hart, P. and Tindall, K. (2009). Understanding Crisis Exploitation: Leadership, Rhetoric and Framing Contests in Response to Economic Meltdown In: P. 't Hart and K. Tindall (eds.) Framing the Global Economic Downturn: Crisis Rhetoric and Politics of Recessions, Canberra: ANU E Press.

Hartcher, P. and Garnaut, J. (2006) 'Bird flu threatens misery for millions'. Sydney Morning Herald, 16 Feb. 2006. Available at:

https://www.smh.com.au/national/bird-flu-threatens-misery-for-millions-20060216gdmzad.html

Hood, C. (2002). The risk game and the blame game., Government and Opposition 37(1): 15-37.

House of Commons (2020). Oral evidence: preparations for the Coronavirus. Health and Social Care Committee HC36, 5 March, https://committees.parliament.uk/oralevidence/113/html/

Hurst, L. (2020). Chief scientific advisor admits UK's coronavirus outcome 'not good'. Euronews 16 July, https://www.euronews.com/2020/07/16/chief-scientificadvisor-admits-uk-s-coronavirus-outcome-not-good

Jacobs, S. (2020). Britain has traded individual liberty for a terrifying state omnishambles. The Telegraph 2 April.

Kamradt-Scott, A. and McInnes, C. (2012). The securitisation of pandemic influenza: framing, security and public policy. Global Public Health (sup2): S95-S110.

Karyotis, G. and Rüdig, W. (2015). Blame and punishment? The electoral politics of extreme austerity in Greece. Political Studies 63(1): 2-24.

Kass, N. E. (2001). An ethics framework for public health. American Journal of Public Health 91(11): 1776-1782.

Kitching, C. (2020). Coronavirus 'could kill 500,000 Brits and infect $80 \%$ ' as thousands face mass GP testing. The Mirror 26 February.

Kuipers, S. and Brändström, A. (2020). Accountability and blame avoidance after crises. In: Oxford Research Encyclopaedia of Politics.

Lancet (2020). Redefining vulnerability in the era of COVID-19, Lancet 395(10230): 1089. 
Liberty (2020). New law is biggest restriction on our freedom in a generation. 26 March https://www.libertyhumanrights.org.uk/issue/new-law-is-biggest-restriction-on-ourfreedom-in-a-generation/

Mason, R. (2020). Hancock accuses those still socialising in UK of being 'very selfish'. The Guardian 23 March.

Matrajt, L., and Leung, T. (2020). Evaluating the effectiveness of social distancing interventions to delay or flatten the epidemic curve of coronavirus disease. Emerging infectious diseases 26(8): 1740.

Merrick, R. (2020a). Coronavirus: less than 20,000 deaths in UK would be 'good result', health chief says. The Independent 28 March.

Merrick, R. (2020b). Coronavirus: Scientists to blame if government made mistakes in response, cabinet minister says. The Independent 19 May, https://www.independent.co.uk/news/uk/politics/coronavirus-uk-lockdown-testingtherese-coffey-science-a9521626.html

Olson, M. (1965). The Logic of Collective Action, Cambridge, Mass: Harvard University Press.

Painter, M., and Qiu, T. (2020). Political beliefs affect compliance with covid-19 social distancing orders. SSRN 3569098.

Paterson, I. and Karyotis, G. (2020) 'We are, by nature, a tolerant people': Securitisation and counter-securitisation in UK migration politics', International Relations. doi: $10.1177 / 0047117820967049$

Proctor, K. (2020). Michael Gove appears to blame China over lack of UK coronavirus testing. The Guardian 29 March.

Rose G. (1985). Sick individuals and sick populations. International Journal of Epidemiology 14: 32-38.

Rosenthal, U., et al. (1989). Coping with crises: the management of disasters, riots, and terrorism, Charles $\mathrm{C}$ Thomas.

Roy, A. (2020). The pandemic is a portal. Financial Times 3 April.

Sanders, D. and Chopra, M. (2003) 'Globalization and the challenge of health for all: a view from sub-Saharan Africa', in Kelley Lee (ed.) Health impacts of globalization: towards global governance. Basingstoke: Palgrave Macmillan.

Scheufele, D.A. (1999). Framing as a theory of media effects. Journal of Communication 49(1): 103-122.

Seawright, J. and Gerring, J. (2008). Case selection techniques in case study research: a menu of qualitative and quantitative options. Political Research Quarterly 61(2): 294-308.

Simanowitz, S. (2020). Herd immunity: timeline of a climb-down. Byline Times 18 March, https://bylinetimes.com/2020/03/18/herd-immunity-timeline-to-a-climb-down/

Simonov, A., et al. (2020). The persuasive effect of Fox News: non-compliance with social distancing during the covid-19 pandemic. National Bureau of Economic Research w27237.

Stewart, H. and Busby, M. (2020). Coronavirus: science chief defends UK plan from criticism. The Guardian 13 March.

Stone, D. (2012). Policy Paradox: the art of political decision making, Third Edition. W.W. Norton \& Company.

Swami, V. and Barron, D. (2020). Analytic thinking, rejection of coronavirus (COVID-19) conspiracy theories, and compliance with mandated social-distancing: direct and indirect relationships in a nationally representative sample of adults in the United Kingdom. https://doi.org/10.31219/osf.io/nmx9w

UK Government (2020a). Prime Minister's statement on coronavirus (COVID-19): 25 March 2020. Retrieved from: https://www.gov.uk/government/speeches/pmstatement-on-coronavirus-25-march-2020 
UK Government (2020c). Foreign Secretary's statement on coronavirus (COVID-19): 7 April 2020. Retrieved from: https://www.gov.uk/government/speeches/foreignsecretarys-statement-on-coronavirus-covid-19-7-april-2020

UK Government. (2020b). Prime Minister's statement on coronavirus (COVID-19): 16 March 2020. Retrieved from: https://www.gov.uk/government/speeches/pmstatement-on-coronavirus-16-march-2020

UK Labour Party (2020). Measures to tackle coronavirus impact must provide economic security for all - Jeremy Corbyn. Retrieved from:

https://labour.org.uk/press/measures-to-tackle-coronavirus-impact-must-provideeconomic-security-for-all-jeremy-corbyn/

UK Parliament (2020). Prime Minister's Questions: 25 March 2020. Retrieved from: https://www.parliament.uk/business/news/2020/march/prime-ministers-questions25-march-2020/

Van Scoy, L. J., et al. (2020). Low Skepticism and Positive Attitudes About Advance Care Planning Among African Americans: a National, Mixed Methods Cohort Study. Journal of General Internal Medicine, 1-8.

Walker, P. (2020). No 10 denies claim Dominic Cummings argued to 'let old people die'. The Guardian, 22 March.

Walt, S. (1991) 'The Renaissance of Security Studies', International Studies Quarterly vol. 35, no. 2, pp. 211-39.

WHO (2005) 'Ten things you need to know about pandemic influenza'. Available at: https://apps.who.int/iris/bitstream/handle/10665/232955/WER8049 50 428431.PDF;jsessionid=24932D997988C43B7E2562BBBFB00E68? sequence $=1$

WHO (2020). Statement on the second meeting of the International Health Regulations (2005) Emergency Committee. Retrieved from https://www.who.int/newsroom/detail/30-01-2020-statement-on-the-second-meeting-of-the-internationalhealth-regulations-(2005)-emergency-committee-regarding-the-outbreak-ofnovel-coronavirus-(2019-ncov)

Williams, M. C. 1998. Modernity, identity and security: a comment on the 'Copenhagen controversy'. Review of International Studies 24(3): 435-439.

Williams-Grut, O. (2020) UK budget watchdog: economy could crash $35 \%$ due to coronavirus lockdown. Yahoo Finance UK 14 April, https://uk.finance.yahoo.com/news/obr-coronavirus-covid-19-lockdown-forecastgdp-unemployment-114954195.html

Wolf, L.J., et al. (2020). The importance of (shared) human values for containing the COVID-19 pandemic. British Journal of Social Psychology 59(3): 618-627. 